\title{
ESTIMATION OF THE NATURAL WATER SELF-PURIFICATION CAPACITY FROM THE KINETIC STANDPOINT
}

\author{
Gheorghe Duca $^{\mathrm{a}}$, Elena Bunduchi ${ }^{*}$, Viorica Gladchi $^{\mathrm{b}}$, Lidia Romanciuc $^{\mathrm{b}}$, Nelli Goreaceva ${ }^{\mathrm{b}}$ \\ ${ }^{a}$ Academy of Sciences of Moldova, Ştefan cel Mare 1, Moldova \\ ${ }^{b}$ Moldova State University, 60 A.Mateevici str. MD 2009, Moldova \\ * ebunduchi@mail.md, phone: 577796,fax: 577557
}

\begin{abstract}
The current paper contains a synthesis of the processes of chemical auto-purification that take place in natural waters; examples of mechanisms of such processes occurring with participation of dissolved organic matter, oxidants of the biogeochemical cycle of oxygen and of transition metals including copper and iron are presented. The kinetic indicators of natural water quality are presented as well.
\end{abstract}

Keywords: self-purification capacity, hydrogen peroxide, free radicals, kinetic indicators, redox state, inhibition capacity

The global cycle of water, together with its property of dissolving gases, organic and mineral compounds determine the various and multicomponent composition of water. At the same time, water represents a natural life environment for living organisms; therefore it is always in a dynamic equilibrated state due to the continuous substances exchange with the aquatic biocenosis.

The various physical, chemical and biological processes in the water reservoirs determine the circuit of chemical substances and living organisms, and the establishment of the quasi-equilibrated state which constitute the basis of biota evolution. The natural self-purification processes were capable to fight the negative changes of water quality just until the anthropogenic action became significant. The excessive anthropogenic pollution damaged this equilibrium, leading to eutrophication of water reservoirs, changes in biocenoses, appearance of toxic effects.

One of the most important priorities of modern science lies in understanding and explaining of the selfpurification capacity of natural waters, i.e. the capacity of diminishing the concentrations of various pollutants to a harmless concentration for ecosystems, as a result of various processes.

The self-purification of surface waters is defined as the totality of biological, physical and chemical processes which take place within the water reservoir and which lead to the diminution of pollutants concentration to a level that is harmless for ecosystems functionality.

Besides chemical compounds that infiltrate into surface waters with waste waters, or atmospheric precipitations, the processes of physical-chemical and chemical-biological transformations include those resulted during the vital activity of living organisms from water reservoirs.

Self-purification of the natural water environment implies physical-chemical processes of mass transfer (physical self-purification), biological self-purification during the metabolic and co-metabolic processes and chemical processes of substances transformation (chemical self-purification).

In fact, physical processes, such as dilution, vaporization or adsorption, lead only to a redistribution of pollutants in the aqueous environment, either amongst the other components of the water reservoir (suspensions, organisms, etc), or by their evacuation in the near-by systems (aquatic basins, bottom depositions, atmosphere).

The involvement of living organisms that are present in water, especially of those autotrophic (algae, bacteria), in the transformation of compounds, leads to the decrease of pollutants concentration due to metabolic and co-metabolic processes. The rate of the microbiological processes in decomposing the substances that don't participate in metabolism is rather small [1,2]. This kind of self-purification is significant only for easily assimilable compounds, such as biogenic substances.

It is known that substances that don't participate in the biologic cycle of biota can undergo transformations due to co-metabolic processes. Still, the efficiency of such processes depends on a multitude of related factors; in case of the majority of compounds, chemical transformations are the most important. As opposed to microbiological processes, chemical and photochemical transformations can unfold in dissolved substances, as well as in those absorbed/adsorbed. Generally, organic pollutants participate only in few chemical transformations [3]:

- hydrolysis, when water is not only a solvent, but a reagent;

- direct, induced and sensitization photolysis, transformations under the influence of sunlight;

- oxidation, when transition metal ions or free ${ }^{\circ} \mathrm{OH}$ radicals act as oxidants; 
a) catalytic, in the presence of $\mathrm{O}_{2}, \mathrm{H}_{2} \mathrm{O}_{2}$ and transition metals ions;

b) radical, in the presence of free ${ }^{\circ} \mathrm{OH}$ radicals.

\section{Hydrochemical indicators for surface waters quality estimation}

As a system of surveillance and control of the environmental state, the monitoring has the tasks of evaluation of the real state and prognostication of possible modifications. The central element of monitoring is the estimation of the state of the environment.

Considering the range of substances which penetrate into and are formed within surface waters, it seems to be difficult and quite useless to control each component in part. There have been elaborated complex indicators which provide the information regarding the content of smaller or larger groups of substances, defined as hydrochemical indicators for the estimation of water quality.

Initially, the monitoring of water quality was based on indexes such as temperature, organoleptic properties, presence of suspensions (turbidity), hydrogen index $(\mathrm{pH})$, redox potential $(\mathrm{Eh})$, hardness, mineralization (content of main ions), content of dissolved oxygen, the chemical (CDO) and biochemical (BDO) doze of oxygen, content of mineral forms of nitrogen $\left(\mathrm{NH}_{4}^{+}, \mathrm{NO}_{2}^{-}, \mathrm{NO}_{3}^{-}\right)$and phosphorus $\left(\mathrm{PO}_{4}^{3-}\right)$, content of heavy metals, organic pollutants (oil products, phenols, pesticides, surface active compounds, etc.). Afterwards, this group of hydrochemical indexes was enlarged with such indicator as: content of $\mathrm{H}_{2} \mathrm{O}_{2}$, redox state, inhibition capacity, named kinetic indicators [4]. Hydrochemical indexes are criteria that allow the correct establishing of the water source quality, its biologic value and utility for specific objectives (drinking, recreation, fish-growing).

In order to quantify and control the content of compounds in waters, the values of field measurements is compared with the admissible concentrations or with fon concentrations. In time it has been demonstrated that these indexes are not informative enough and can't explain the causes of changes that take place in water ecosystems, such as biocenoses change, appearance of toxicity for organisms living in waters and even for man. For example, the admissible limit concentration established for copper ions in hard water using the concentrations of aqua-forms can't be used with certainty in real conditions. In the natural water environment, living organisms can be submitted to a certain deficit of biologically accessible forms even in case of concentrations larger than the admissible limit concentration, due to certain specific properties of ions, such as: small charge, high capacity of copper (II) ions to form complexes, formation of stable compounds of copper (I) and several natural ligands. Also, the concentrations of organic pollutants and biogenic elements are not sufficient for the characterization of surface water quality. Thus, depending on the qualitative composition of organic compounds which determine the chemical doze of oxygen, surface waters can be biologically valuable at high CDO values and, in contrast, toxic at low CDO values. The method of comparison of the determined concentration with the admissible limit can, certainly, be applied only in case of compounds, such as the main ions $\left(\mathrm{Ca}^{2+}, \mathrm{Mg}^{2+}, \mathrm{Na}^{+}, \mathrm{K}^{2+}, \mathrm{CO}_{3}^{2-}, \mathrm{HCO}_{3}^{-}, \mathrm{SO}_{4}^{2-}, \mathrm{Cl}^{-}\right)$which form the so-called mineralization of natural waters, as for the remaining components, their quantity is permanently changing, due to the variation of several factors.

Kinetic indicators of surface water quality characterize the content and dynamics of products of mono-electron

activation of oxygen, such as highly reactive redox agents: hydroxyl radicals ( $\dot{\mathrm{O}} \mathrm{H})$, singlet oxygen $\left({ }^{1} \mathrm{O}_{2}\right)$, superoxide anions $\left(\mathrm{H}_{2}\right)$ and the product of bi-electron activation - hydrogen peroxide $\left(\mathrm{H}_{2} \mathrm{O}_{2}\right)$. The value and the dynamics of these indexes are of significant importance in establishing the quality class of the water object, its biological value and the self-purification capacity of the natural water [3-6].

One of the properties of surface waters is the redox state. It has been considered for a long time that the main indicator of the oxidative state is the presence of molecular oxygen in the water, and the reducing state is characterized by its absence and the presence of iron (II). However, as a result of numerous field measurements and observations, it has been demonstrated that the state of surface waters can be considered normal (oxidative) only in cases when besides the dissolved $\mathrm{O}_{2}$ the waters contain hydrogen peroxide $\left(\mathrm{H}_{2} \mathrm{O}_{2}\right)$ in physiological quantities, set as favorable for living organisms: $9 \cdot 10^{-9} \mathrm{M}<\mathrm{H}_{2} \mathrm{O}_{2}<9 \cdot 10^{-6} \mathrm{M}\left(0,3 \mu \mathrm{g} / 1<\mathrm{H}_{2} \mathrm{O}_{2}<300 \mu \mathrm{g} / \mathrm{l}\right)$ [6-9].

These observations lead to the conclusion that hydrogen peroxide is an indispensable component of the water environment.

Evolution made it natural that organisms live in oxidative conditions and die in reducing media. For example, daphnia and infusorians, juvenile fish, die shortly in case the hydrogen peroxide is absent in the environment. The juvenile fish needs the $\mathrm{H}_{2} \mathrm{O}_{2}$ as exogenic oxidant until the formation of its own oxidation systems. The lack $\mathrm{H}_{2} \mathrm{O}_{2}$ is characterized by the domination of reducing compounds which can act through blocking the oxidation-reduction centers f enzymes, damaging the redox equilibrium within the cell. Another impact of the domination of reducing conditions is the burst of pathogenic microflora, which eliminates toxins that can affect even man [3, 7-9].

Field measurements have shown cases when $\mathrm{H}_{2} \mathrm{O}_{2}$ was absent in surface waters, but other significantly oxidative 
compounds were observed [23]. Therefore, dynamic redox state can be created in the natural water environment, depending on the $\mathrm{H}_{2} \mathrm{O}_{2}$ concentration in water, of reducing agents and highly oxidative compounds $[4,6,9]$ :

- oxidative, the $\mathrm{H}_{2} \mathrm{O}_{2}$ is present in concentrations of $10^{-6}-10^{-5} \mathbf{~ m o l} / \mathrm{l}$

- quasi-reducing ( $\left.\boldsymbol{R e d}_{e}\right), \mathrm{H}_{2} \mathrm{O}_{2}$ is absent and compounds with significant reducing properties are identified, which are titrated by $\mathrm{H}_{2} \mathrm{O}_{2}$ (phenols, dienols, sulfur compounds etc.)

- super-oxidative $\left(\boldsymbol{O} x_{e f}\right)$ - products and half-products of technological cycles are detected (active chlorine, $\left.\mathrm{Cr}(\mathrm{VI}), \mathrm{KMnO}_{4}\right)$.

The moment of appearance and the duration of instable states can change from season to season, but the qualitative aspect remains the same. It has been observed that in the case of redox state change, the classical hydrochemical and hydrobiological indexes remain almost the same.

The biologically valuable state of surface waters is considered to be its oxidative state, when besides the dissolved $\mathrm{O}_{2}$ the water contains $\mathrm{H}_{2} \mathrm{O}_{2}$ in physiologically favorable concentrations for living organisms $-10^{-6}-10^{-5} \mathrm{~mol} / \mathrm{l}$.

The process of formation and decomposition of $\mathrm{H}_{2} \mathrm{O}_{2}$ in natural waters is accompanied by the formation of free radicals. Amongst all intermediate products of oxygen reduction, the $\mathrm{OH}$ radical is considered the most powerful oxidant, due to its high redox potential $(2,8 \mathrm{~V})$. It interacts with most of organic substances with rate constants practically equal to the diffusion constant $\mathrm{k}_{\mathrm{OH}+\mathrm{P}}=10^{8}-10^{10} \mathrm{~mol}^{-1} \mathrm{~s}^{-1}[11]$.

The stationary concentration of $O H$ radicals in natural waters is quite low, of the $10^{-17}-10^{-15} \mathrm{M}$ order [9, 12-15]. Considering the reactivity towards $\dot{O} H$ radicals, the components of natural waters form two groups [3]:

- substances whose radicals react either with $\mathrm{O}_{2}$, or with transition metals ions, generating $\dot{O} H$ in the end. The rate of oxidation of each component from this chain is determined by the stationary concentration of $\dot{O} H$.

- substances whose radicals possess a low reactivity or, after undergoing transformations, become unreactive.

These compounds, at there turn, can become $\dot{O} H$ traps or compounds which react with this radical and then form with $\mathrm{O}_{2}$ a peroxide radical, with low reactivity. Afterwards, these radical disappear due to recombination, disproportionation or the reaction with the reducing form of the metal. As a result, radical chains are destroyed.

The effective rate constant which characterizes the interaction of $\dot{O} H$ with all components of this group makes the second category a parameter which characterizes the capacity of natural waters to inhibit radical self-purification processes through $\dot{O} H$ radicals. The inhibition capacity is the effective constant of the rate of destruction of $\dot{O} H$ radicals.

Considering the criterion capacity to inhibit radical self-purification processes of natural waters, they can be divided into three categories $[3,4,6]$ :

1) if $\Sigma \mathrm{k}_{\mathrm{i}}\left[\mathrm{S}_{\mathrm{i}}\right]<3 \cdot 10^{4} \mathrm{~s}^{-1}-$ very clean waters

2) if $\Sigma \mathrm{k}_{\mathrm{i}}\left[\mathrm{S}_{\mathrm{i}}\right] 3 \cdot 10^{4}-3 \cdot 10^{5} \mathrm{~s}^{-1}-$ normal state of natural waters

3) if $\Sigma \mathrm{k}_{\mathrm{i}}\left[\mathrm{S}_{\mathrm{i}}\right]>3 \cdot 10^{5} \mathrm{~s}^{-1}-$ highly polluted waters.

The dynamics of the content of redox agents in natural waters is an index of the biocenosis state: homeostasis, reversible and irreversible perturbation. Excessively high or low values of indices, accompanied by an unclear dynamics correspond to an ecosystem with irreversibly disturbed ecological welfare. In a normal aquatic ecosystem, the range of variation of the rate of formation and lifetime of redox agents doesn't exceed with $\pm 50 \%$ any mean value, which formed under the influence of meteorological, hydro-physical, hydrochemical etc. factors.

The quality of natural waters must be defined not by its content of specific substances, but by its biological value. Waters with adequate biological value represent a good environment where vital processes unfold normally at various trophic levels, so that the cycle of chemical compounds is closed.

\section{Redox components of surface waters}

The chemical circuit of water in nature is tightly correlated with redox processes which involve molecular oxygen, hydrogen peroxide and other active particle from the biogeochemical cycle of oxygen.

The vital activity of aquatic organisms is based on the biogeochemical cycle of oxygen which, in its turn, is correlated with other biogeochemical cycles (of nitrogen, sulfur, variable valence metals). The concentration of dissolved oxygen in surface waters ranges between 0 and $14 \mathrm{mg} / \mathrm{l}$ and is determined by two processes - photosynthesis and the biotic and abiotic consumption. Due to photosynthesis, there is enough oxygen in the atmosphere to oxidize all organic compounds on Earth. After fluorine, it is the next most powerful oxidant; it eliminates $491 \mathrm{~kJ} / \mathrm{mol}$ of free 
energy during its reduction to water. However, in spite of it being a strong oxidant from the thermodynamic point of view, oxygen is quite inert from the kinetic standpoint. This is due to its specific electronic structure, which determines the triplet state of oxygen as its ground state [10,39].

As tot the chemistry of natural waters, the products of oxygen activation are the most important in the oxidation and reduction processes within the basin, as they are considered the most reactive elements of the biogeochemical cycle of oxygen. In fact, oxygen reactivity is not determined by its molecular form, but by the intermediates of its biogeochemical cycle $\left({ }^{1} \mathrm{O}_{2}, \dot{\mathrm{O}} \mathrm{H}, \mathrm{O}_{2}^{\bullet-}, \mathrm{H}_{2} \mathrm{O}_{2}\right)$. Numerous field measurements allowed establishing the stationary concentrations of these particles: $\left[{ }^{1} \mathrm{O}_{2}\right]=10^{-14}-10^{-12} \mathrm{M},[\dot{O} H]=10^{-18}-10^{-15} \mathrm{M},\left[\mathrm{H} \dot{O_{2}}\right]=10^{-8}-10^{-9} \mathrm{M},\left[\mathrm{H}_{2} \mathrm{O}_{2}\right]=$ 10-6-10-5 M (Zерp R.G., 1977; Hoigne Z., 1979; Mill T., 1980; Zafiriou O.C., 1983; Скурлатов Ю.И., 1983, Duca Gh., 1983, 1988, 2000, 2006; Штамм Е.В., 1991; Эрнестова Л.С., 1995; Grannas A. М., 2006) [9, 14-19].

According to thermodynamic data of redox $\left(\varphi_{\mathrm{HO} / \mathrm{H} 2 \mathrm{O} 2}=1,44 \mathrm{~V}\right)$ and acid-base $\left(\mathrm{pK}_{\mathrm{a}}=11,75\right)$ transformations of oxygen, the most stable intermediate product of $\mathrm{O}_{2}$ reduction is hydrogen peroxide $\left(\mathrm{H}_{2} \mathrm{O}_{2}\right)$ [10].

The majority of $\mathrm{H}_{2} \mathrm{O}_{2}$ in surface waters comes from photochemical generating processes. During the action of sunlight on organic dissolved substances (ODS), the superoxide anion radical results, being the precursor of $\mathrm{H}_{2} \mathrm{O}_{2}$ in natural waters:

$\mathrm{ODS} \stackrel{h v}{\longrightarrow} \mathrm{O}_{2}^{\bullet-} \stackrel{+2 \mathrm{H}^{+}}{\longrightarrow} \mathrm{H}_{2} \mathrm{O}_{2}+\mathrm{O}_{2}$

Some quantity of $\mathrm{H}_{2} \mathrm{O}_{2}$ results in redox-catalytic processes:

$\mathrm{O}_{2}+\mathrm{DH}_{2} \stackrel{\mathrm{Cu}^{2+} / \mathrm{Cu}^{+}}{\longrightarrow} \mathrm{H}_{2} \mathrm{O}_{2}+\mathrm{D}$

Biologic emissions form another source of $\mathrm{H}_{2} \mathrm{O}_{2}$. Many species of algae are known, which eliminate in the environment the over-produced $\mathrm{H}_{2} \mathrm{O}_{2}$, formed in cells during photosynthesis. Also, on the exterior surface of several algae there are ferments, such as diaminases, which can oxidize organic compounds of nitrogen:

$\mathrm{R}-\mathrm{CHNH}_{3} \mathrm{COO}+\mathrm{H}_{2} \mathrm{O}+\mathrm{O}_{2} \longrightarrow \mathrm{R}-\mathrm{CHOCOO} \mathrm{NH} \mathrm{N}_{4}+\mathrm{H}_{2} \mathrm{O}_{2}$

The amount of $\mathrm{H}_{2} \mathrm{O}_{2}$ can increase due to hydro-peroxides:

$\mathrm{ROOH}+\mathrm{H}_{2} \mathrm{O} \stackrel{\mathrm{ROH}}{\longrightarrow} \mathrm{H}_{2} \mathrm{O}_{2}$

In stationary conditions, mean concentrations of hydrogen peroxide range between $10^{-6}-10^{-5} \mathrm{M}$. The decomposition of $\mathrm{H}_{2} \mathrm{O}_{2}$ in natural waters is triggered by biotic and abiotic processes. On the basis of numerous researches, it has been established that among potential catalysts of decomposition processes, the most active in natural waters are ions and complexes of copper and iron. Biotic destruction is determined by microalgae content.

Considering the mentioned above thermodynamic data, we can deduce that the most reactive particle from the oxygen cycle is $\dot{O} H$ [10]. According to the specialty literature, the main mechanism of these radicals initiation is the photochemical one, namely the photolysis of organic compounds dissolved in water and of several inorganic components, such as: nitrates, nitrites, peroxides, complexes of variable valence metals ( $\mathrm{Fe}, \mathrm{Cu}, \mathrm{Mn}, \mathrm{Cr}$ ):

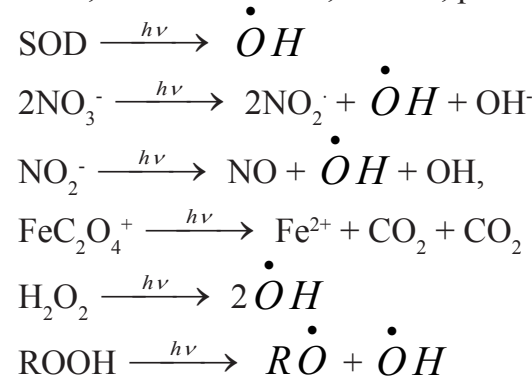

The hydroxyl radical is the most reactive intermediate, non-selective and electrophilic. The second order constant of this oxidant with numerous organic compounds has values close to the diffusion constant $\left(10^{7}-10^{10} \mathrm{M} \cdot \mathrm{s}^{-1}\right)$ [11]. Although it is present in natural waters in concentrations around 10-14 $-10^{-18} \mathrm{M}$ (Brezonik, 1998; Russi, 1982; Скурлатов Ю.И., 1983; Duса Gh., 1983, 1988, 2000, 2006; Штамм E.В., 1991; Эрнестова Л.С., 1995; Grannas A. M., 2006) this photo-oxidant significantly contributes to reactions of limitation of organic contaminants in natural waters [9, 14-19]. The reactions with $\dot{O} H$ participation are the hydrogen atom abstraction and its addition to the double bond [10].

Measurements regarding the influence of the wavelength on the rate of $\dot{O} H$ generation by the ODS solutions contained in arctic waters have indicated that the highest amount of $\dot{O} H$ is obtained at the wavelength of $\approx 300 \mathrm{~nm}$ [15]. Another drawn conclusion is that the quantity generated is function of the applied wavelength and isn't influenced almost at all by the geographical place of the water reservoir from which the ODS have been preloaded. This conclusion 
came up after comparing the data obtained by several researchers. Thus, the values for the $\dot{O} H$ initiation reaction obtained at the irradiation of arctic waters which contain $10^{-12} \mathrm{M} \cdot \mathrm{s}^{-1} \mathrm{ODS}$, are comparable with the values obtained by Mooper and Zhou in Gulf Stream waters - around $14,7 \cdot 10^{-12} \mathrm{M} \cdot \mathrm{s}^{-1}$, and ocean waters - $15,9 \cdot 10^{-12} \mathrm{M} \cdot \mathrm{s}^{-1}[12,15]$. Again, Mooper and Zhou, have measured the photochemical production in natural water submitted to irradiation and observed from $2,8 \cdot 10^{-12} \mathrm{M} \cdot \mathrm{s}^{-1}$ - in open ocean water, up to $420 \cdot 10^{-12} \mathrm{M} \cdot \mathrm{s}^{-1}$ for surface waters. Values of $\dot{O} H$ initiation rates of $10^{-11} \mathrm{M} \cdot \mathrm{s}^{-1}$ have resulted in investigations of the river Volga (Rusia), rivers Prut and Nistru (Moldova) [14, 23].

Measurements made by Vaughan and Blough (1998) regarding the generation of $\dot{O} H$ by fulvoacids (at 320 $\mathrm{nm})$, resulted in values of $2 \cdot 10^{-11} \mathrm{M} \cdot \mathrm{s}^{-1}$ (or $5 \cdot 10^{-12} \mathrm{M} \cdot \mathrm{s}^{-1} \mathrm{ppm}^{-1} \mathrm{C}$ ) [13]. After the extrapolation of their results for $320 \mathrm{~nm}$, Grannas A. M. et al. (2006), obtained the value of $2 \cdot 10^{-12} \mathrm{M} \cdot \mathrm{s}^{-1} \mathrm{ppm}^{-1} \mathrm{C}[15]$.

Besides the photochemical reactions, $\dot{O} H$ radicals can be formed in processes with the participation of transition metals ions and reducing compounds with complexes' properties [20-22]:

$$
\mathrm{CuD}+\mathrm{H}_{2} \mathrm{O}_{2} \rightarrow \mathrm{Cu}^{2+}\left(\mathrm{OH}^{-}\right)+\dot{O} H+D^{\bullet-}
$$

The catalytic destruction of $\mathrm{H}_{2} \mathrm{O}_{2}$ in the presence of copper (I) ions is accompanied by the formation of $\mathrm{OH}$ radicals:

$$
\stackrel{\mathrm{Cu}}{+}+\mathrm{H}_{2} \mathrm{O}_{2} \rightarrow(\mathrm{CuO})^{+} \mathrm{H}_{2} \mathrm{O} \rightarrow \mathrm{Cu}^{2+}\left(\mathrm{OH}^{-}\right)+\dot{O} H
$$

In the case of water solubilization of ozone $\left(\mathrm{O}_{3 \cdot \mathrm{aq}}\right.$, with a concentration in surface waters of around $\left.10^{-8} \mathrm{M}\right)$ and its subsequent interaction with the dissociated form of $\mathrm{H}_{2} \mathrm{O}_{2}$, its destruction takes place according to a radical chain mechanism [17, 19]:

$$
\mathrm{O}_{3 \cdot \mathrm{aq}}+\mathrm{HO}_{2}^{-} \rightarrow \mathrm{OH}+\mathrm{O}_{2}
$$

Also, $\mathrm{OH}$-radicals are formed during the interaction of reducing substances with ozone:

$$
\mathrm{O}_{3}+\mathrm{DH}^{-} \rightarrow \dot{\mathrm{O}} \mathrm{H}+\mathrm{D}^{\bullet-}+\mathrm{O}_{2}
$$

The formation of free $\mathrm{OH}$ radicals inevitably leads to the generation of secondary radicals. Mill et al. in a range of photochemical studies on natural water samples, identified, besides the $\mathrm{OH}$ radicals, concentrations of $3 \cdot 10^{-9} \mathrm{M}$ of alkyl peroxide radicals [18]:

$$
\begin{aligned}
& \mathrm{RH}+\dot{\mathrm{O} H} \rightarrow \dot{R}+\mathrm{H}_{2} \mathrm{O} \\
& \dot{\mathrm{R}}+\mathrm{O}_{2} \rightarrow \dot{\mathrm{RO}_{2}}
\end{aligned}
$$

The constants that describe the interaction of $\dot{R} O_{2}$ radicals with many organic substances are, commonly, smaller than $1 \mathrm{M}^{-1} \cdot \mathrm{s}^{-1}$. Due to the oxidation with peroxide radicals, the lifetime of chemical reactive species, such as phenols, aromatic amines, hydroxylamines, poliphenols, constitutes several days.

According to the data obtained by Zepp et al. under the influence of sunlight the effective generation of singlet oxygen takes place in natural waters, with a stationary concentration of $10^{-14}-10^{-12} \mathrm{M}$ [16]. This value is proportional to the content of dissolved humic compounds in water.

$$
\begin{aligned}
& \mathrm{S} \stackrel{h_{v}}{\longrightarrow}{ }^{1} \mathrm{~S}^{*} \longrightarrow{ }^{3} \mathrm{~S}^{*} \\
& { }^{3} \mathrm{~S}^{*}+\mathrm{O}_{2} \longrightarrow{ }^{1} \mathrm{O}_{2}+\mathrm{S}
\end{aligned}
$$

Singlet oxygen $\left({ }^{1} \mathrm{O}_{2}\right)$ is an effective oxidant for compounds which contain double bonds with high electronic density or readily oxidized functional groups (alkyl sulfide, thiol, phenolate ions etc.). These compounds have lifetimes of hours.

Besides the singlet oxygen, humic compounds photolysis results in free electrons. In the natural aquatic environment, solvated electrons $\left(\overline{\mathrm{e}}_{\mathrm{aq}}\right)$ interact with dissolved oxygen, forming the superoxide anion radical ( $\left.\mathrm{O}_{2}^{\bullet-}\right)$, which is the precursor of an effective oxidant - hydrogen peroxide $\left(\mathrm{H}_{2} \mathrm{O}_{2}\right)$ :

$$
\overline{\mathrm{e}}+\mathrm{O}_{2} \longrightarrow \mathrm{O}_{2}^{\bullet-} ; 2 \mathrm{O}_{2}^{\bullet-}+2 \mathrm{H}^{+} \longrightarrow \mathrm{H}_{2} \mathrm{O}_{2}+\mathrm{O}_{2}
$$

The general photochemical scheme of DOS transformation under the influence of sunlight can be drawn as:

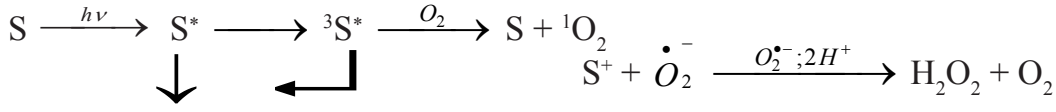

$$
\begin{aligned}
& \begin{array}{l}
\mathrm{S}^{+}+\overline{\mathrm{e}}_{\mathrm{aq}} \stackrel{\mathrm{O}_{2}}{\longrightarrow} \dot{\mathrm{O}}_{2}^{-} \\
\stackrel{\mathrm{RO}_{2}}{\downarrow}, \dot{\mathrm{R} O}, \mathrm{ROOH}
\end{array}
\end{aligned}
$$


One very important specific of natural waters is the presence of micro-quantities of transition metals in it. These components can participate in reactions with intermediate free radicals, hydrogen peroxide, and molecular oxygen. Metals can form various complexes with natural waters components which possess ligand properties, catalytic properties in redox transformations or which participate in photochemical processes $[10,35,36]$.

The results obtained in model and natural conditions have demonstrated that in the natural aquatic environment and a $\mathrm{pH}$ value between 5 and 9 (characteristic for surface waters), almost all metals with variable valence are found predominantly as colloids of oxide or hydroxide or as soluble complexes, with natural ligands [35, 36]. Given that surface waters are oxidative environments in normal conditions, transition metals ions are found mainly in oxidized form $\left(\mathrm{M}^{2+}\right)$. Only a small quantity of metals is in reduced form $\left(\mathrm{M}^{+}\right)$, and it participates in the activation of $\mathrm{O}_{2}$ and $\mathrm{H}_{2} \mathrm{O}_{2}$. Among all transition metals in surface waters, especially important for redox transformations are copper, iron and manganese. Only copper ions exist in neutral environment in homogenic form, both in oxidized $\left(\left[\mathrm{Cu}^{2+}=3 \cdot 10^{-7}\right.\right.$ $\mathrm{mol} / \mathrm{l}])$, and in reduced form $\left(\left[\mathrm{Cu}^{+}=10^{-8} \mathrm{~mol} / \mathrm{l}\right]\right)$. Iron ions are found in aerobic conditions mainly in oxidized form, as micro-colloids of hydroxide $(\equiv \mathrm{FeOOH})$, at concentrations of $10^{-5} \mathrm{~mol} / \mathrm{l}$. The highest concentration of the solvated form of the compound $\equiv \mathrm{FeOOH}$ is of $2 \cdot 10^{-7} \mathrm{~mol} / 1$ [24]. The soluble forms of iron (III) are represented especially by anionic hydroxy-fulvic complexes [35, 36]. Manganese ions are found either as free ions $\mathrm{Mn}^{2+}$, or as micro-colloids of Mn (IV) hydroxide, which is formed in natural conditions at biological oxidation of $\mathrm{Mn}$ (II) [25].

A characteristic of copper ions is their participation in reactions of one- or two-electrons transfer, leading to the formation of free $\dot{O} H$ radicals and superoxide radical $O_{2}^{\bullet-}$. As to iron and manganese ions, they participate in catalytic reactions of $\mathrm{H}_{2} \mathrm{O}_{2}$ decomposition with a two-electrons transfer [26].

Besides oxidants and catalysts (transition metals), in the oxidation-reduction processes also participate various reducing compounds, which can be formed directly in the aquatic environment (autochthonous compounds, metabolic products and those of biochemical destruction) or infiltrate in it with precipitations, floods or waste waters (alochthonous substances). Organic compounds are present in surface waters in relatively small concentrations, especially $<0,1 \mathrm{mg} / 1$ or $<10^{-5} \mathrm{M}[36]$.

\section{Modeling of redox transformations in the natural aquatic environment}

From the chemical-kinetic point of view, natural waters form an open oxidation-reduction system; oxidizing and reducing compounds continuously infiltrate in it.

According to the database accumulated by various researchers, the chemical composition of the abiotic component of natural waters can be represented as follows:

$\mathrm{S}-\mathrm{A}-\mathrm{O}_{2, \mathrm{aq}}-\mathrm{H}_{2} \mathrm{O}_{2}-\left\{\mathrm{R}_{\mathrm{x}}\right\}-\mathrm{Me}^{\mathrm{n}+} / \mathrm{Me}^{(\mathrm{n}-1)+}-\mathrm{L}-\mathrm{Sed}$

where $\mathrm{O}_{2, \mathrm{aq}}-\mathrm{H}_{2} \mathrm{O}_{2}-\left\{\mathrm{R}_{\mathrm{x}}\right\}$ - dissolved molecular oxygen and its activation products; $\mathrm{S}-$ substrates of chemical transformations, including anthropogenic pollutants, $\mathrm{A}$ - active particles acceptors, which form secondary, less active radicals, $\mathrm{Me}^{\mathrm{n}+} / \mathrm{Me}^{(\mathrm{n}-1)^{+}}-$ions and complexes of transition metals in oxidized/reduced form; $\mathrm{L}$ - components with ligand properties; Sed - suspensions with various dispersion rate, which form the heterogeneous phase.

The oxidation-reduction processes exist in natural waters only due to the presence of oxidative equivalents $\left(\mathrm{M}^{\mathrm{n}+}, \mathrm{O}_{2}, \mathrm{H}_{2} \mathrm{O}_{2}, O H\right)$, reducing agents $\left(\mathrm{DH}_{2}\right)$ and catalysts $\left(\mathrm{M}^{(\mathrm{n}-1)+} / \mathrm{M}^{\mathrm{n}+}\right)$. It should be mentioned that the redox model of natural waters doesn't include analysis of redox reactions that take place due to other oxidants that can infiltrate into waters as a result of anthropogenic pollution or chemical-biological transformations, but molecular oxygen and hydrogen peroxide. It is considered that these processes can be described by the laws established for catalytic oxygenperoxide systems.

In order to involve $\mathrm{O}_{2}$ in oxidation processes chemical energy is necessary to activate it. This can happen on the account of sunlight absorption or interaction with compounds with significant reducing properties (metal ions in reducing forms, free radicals).

Hydrogen peroxide, the product of bi-electronic reduction of $\mathrm{O}_{2}$, is considered the carrier of oxidative equivalents of oxygen in natural waters. As opposed to $\mathrm{O}_{2}, \mathrm{H}_{2} \mathrm{O}_{2}$ can exhibit reducing and oxidizing properties in neutral environment, depending on its redox partner; thus it can interact with reduced and oxidized metal ions.

Among the transition metals present in natural waters, the most important for redox transformations are copper, iron and manganese ions.

Qualitative kinetic characteristics allow the prognostication of possible concentrations of compounds in waters with various loads, the estimation of maximal quantity of substance which can be discharged in water without disturbing the self-purification processes within the reservoir. The kinetic characteristic of processes is the effective rate constant, which is a function of the environment's parameters. 
Much data exist nowadays regarding the chemical composition of natural waters, but very little is known about the kinetic laws that describe the interactions between these compounds [10, 39, 40]. A number of systems, such as $\mathrm{M}^{2+} / \mathrm{M}^{+}-\mathrm{L}-\mathrm{S}-\mathrm{O}_{2} / \mathrm{H}_{2} \mathrm{O}_{2}$ (where, $\mathrm{M}^{2+} / \mathrm{M}^{+}$variable valence metal in oxidized/reduced form, $\mathrm{L}$ - ligand, $\mathrm{S}$ - substrate) have been studied. There is a lot of data on thermodynamic properties of metal complexes, reactivity of intermediate free radicals, mechanisms of activation of $\mathrm{O}_{2}$ and $\mathrm{H}_{2} \mathrm{O}_{2}$; however very little is known about catalytic oxidation of several compounds of significant ecological importance.

Among all reducing agents which model the most successfully natural reducing compounds, most extensively studied are the ascorbic acid [20], thiolic compounds [27, 28], hydrochinone [27, 29], oxy and hydroxyacids [21, 22]. The ascorbic acid is a compound that regulates the intracellular redox state, having a significant medical-biological role. Oxy- and hydroxyl acids form the metabolic cycle of dicarboxylic acids and take part in the exchange of substances of living organisms with the environment. Hydroquinone is one of the poliphenols very often encountered in surface waters, being the precursors of natural humus. Thiolic compounds participate in metabolic processes of microorganisms, are used in the leather industry, in fertilizers technology etc.

On the basis of ascorbic acid the redox mechanism of processes within the aquatic environment has been established, with the participation of ions and complexes of copper when the pollutant $(\mathrm{P})$ possesses ligand properties or significant reducing properties [20]. During the interaction between the metal and P, a compound with partial charge transfer is formed $\left(\mathrm{CuDH}^{+}\right)$:

$$
\mathrm{Cu}^{2+}\left(\mathrm{OH}^{-}\right)+\mathrm{DH}^{-} \leftrightarrows \mathrm{CuDH}^{+}+\mathrm{OH}^{-}
$$

This complex plays the role of a one-electron donator, reducing the peroxide to $\dot{O} H$ radicals, whereas the metal ion doesn't change its oxidation state:

$$
\mathrm{CuDH}^{+}+\mathrm{H}_{2} \mathrm{O}_{2} \rightarrow \mathrm{Cu}^{2+}+D^{\bullet-}+\dot{\mathrm{O}} \mathrm{H}+\mathrm{H}_{2} \mathrm{O}
$$

And this lead to the initiation of processes of conjugated oxidation of pollutants in natural water.

In the case of small copper ions concentrations, the complex can decompose in products with one-electron transfer:

$$
\mathrm{CuDH}^{+} \rightarrow \mathrm{Cu}^{+}+\mathrm{DH}^{\cdot}\left(D^{\bullet-}+\mathrm{H}^{+}\right)
$$

And in the case of high metal ions concentrations, it can interact with the second copper ion, thus oxidizing the donor by the two-electron pathway:

$$
\mathrm{CuDH}^{+}+\mathrm{CuOH}^{+} \rightarrow 2 \mathrm{Cu}^{+}+\mathrm{D}+\mathrm{H}^{+}
$$

Given the copper ions concentration in natural waters, which is around $\approx 10^{-7} \mathrm{M}$, the one-electron mechanism prevails in these conditions.

The discussed system is characterized by a specificity regarding the formation of $\mathrm{OH}$ radicals. As opposed to the Phenton system, the generation of $\dot{O} H$ radicals doesn't interfere with the valence of the metal, this one remaining in its oxidized form. Copper (I) ions appear in this system as secondary particles, formed as a result of $\mathrm{H}_{2} \mathrm{O}_{2}$ destruction:

$$
\begin{gathered}
\dot{\mathrm{O} H}+\mathrm{H}_{2} \mathrm{O}_{2} \longrightarrow \dot{H}_{2} \\
\dot{H}_{2}+\mathrm{Cu}^{2+} \longrightarrow \mathrm{Cu}^{+}+\mathrm{O}_{2}+\mathrm{H}^{+}
\end{gathered}
$$

The impact of compounds with don't exhibit ligand properties in the natural aquatic environment (such as hydroquinone, glyoxalic acid) $[28,44]$ can be positive or negative, depending on the substrate's concentration. During the interaction of copper (I) ions with $\mathrm{H}_{2} \mathrm{O}_{2}$, the particle $\mathrm{CuO}^{+}$results (which can be treated as the hydrolyzed $\mathrm{Cu}^{3+}$ ion), being the precursor of the $\dot{O} H$ radical [34]:

$$
\mathrm{Cu}^{+}+\mathrm{H}_{2} \mathrm{O}_{2} \longrightarrow \mathrm{CuO}^{+}+\mathrm{H}_{2} \mathrm{O}
$$

In the absence of reactive substrates, this particle oxidizes water, forming $\mathrm{OH}$ radicals:

$$
\mathrm{CuO}^{+}+\mathrm{H}_{2} \mathrm{O} \longrightarrow(\mathrm{CuOH})^{+}+\mathrm{OH}
$$

Given the fact that it is a two-electrons acceptor towards substrates, in the presence of $\mathrm{H}$ donors it oxidizes the donor according to the two-electrons pathway:

$$
\mathrm{CuO}^{+}+\mathrm{QH}_{2} \longrightarrow \mathrm{Cu}^{+}+\mathrm{Q}+\mathrm{H}_{2} \mathrm{O}
$$

Thus, depending on the donors concentration in the environment, processes of inhibition or generation of $\mathrm{OH}$ radicals can take place.

Considering all stated above, the presence of reducing agents with no ligand properties has two roles: at small concentrations, substrates will nor essentially interfere the process of $\mathrm{OH}$ radicals generation, as a result of water oxidation by $\mathrm{CuO}^{+}$(i.e. $\mathrm{CuO}^{+}$will oxidize intensely the waters molecules and will be less consumed for the $\mathrm{QH}_{2}$ oxidation), at high concentrations, these substances will act as inhibitors, trapping the $\mathrm{CuO}^{+}$particle, which is the precursor of $\mathrm{OH}$ radicals. This is of significant importance for the realization of chemical self-purification processes of natural waters, due to the possibility of conjugated oxidation. 
Sulfur compounds posses significant reducing and ligand properties (such as glutathione, thioureea, cysteine), but these compounds form stable complexes with low reactivity on interaction with copper ions (II) [27, 44].

The mechanism describing the processes of catalytic oxidation of cysteine, thioureea and glutathione are very much alike. The redox process unfolds with the formation of the intermediate complex of the thiol with the transition metal ions:

$$
\begin{aligned}
& 2 \mathrm{Cu}^{2+}+2 \mathrm{GSH} \longrightarrow 2 \mathrm{Cu}^{+}+\mathrm{GSSG} \\
& \mathrm{Cu}^{+}+\mathrm{GSH} \rightleftarrows \mathrm{CuGSH}^{+}, \text {mono-complex } \\
& \mathrm{CuGSH}^{+}+\mathrm{GSH} \rightleftarrows \mathrm{Cu}(\mathrm{GSH})_{2}^{+}, \text {bi-complex }
\end{aligned}
$$

which can subsequently react with the dissolved oxygen or hydrogen peroxide.

During the oxygen driven oxidation, the process includes two metal ions:

$\mathrm{Cu}(\mathrm{GSH})_{2}^{+}+\mathrm{O}_{2} \rightleftarrows(\mathrm{CuGSH})_{2} \mathrm{CuO}_{2}^{+}$

$\mathrm{Cu}(\mathrm{GSH})_{2}^{+}+(\mathrm{CuGSH})_{2} \mathrm{CuO}_{2}^{+} \longrightarrow 2 \mathrm{Cu}^{+}+2 \mathrm{GSSG}+2 \mathrm{H}_{2} \mathrm{O}$

whilst in the case of hydrogen peroxide driven oxidation, only one metal ion participates in the transformations:

$\mathrm{Cu}(\mathrm{GSH})_{2}^{+}+\mathrm{H}_{2} \mathrm{O}_{2} \rightleftarrows \mathrm{Cu}^{+}+\mathrm{GSSG}+2 \mathrm{H}_{2} \mathrm{O}$

The mechanism of these processes is ion-molecular of activated type. The oxidation of thiols by hydrogen peroxide is a very rare case, when no free radicals are formed.

In case of heterogeneous catalysts, such as iron microcolloids, peroxide decomposition:

$-\mathrm{Fe}(\mathrm{III})-\mathrm{O}-\mathrm{Fe}(\mathrm{III})-+\mathrm{H}_{2} \mathrm{O}_{2} \longrightarrow-\mathrm{Fe}(\mathrm{II}) \cdots \mathrm{Fe}(\mathrm{II})-+\mathrm{O}_{2}$

and compounds oxidation:

$-\mathrm{Fe}(\mathrm{III})-\mathrm{O}-\mathrm{Fe}(\mathrm{III})+\mathrm{DH}_{2} \longrightarrow-\mathrm{Fe}(\mathrm{II}) \cdots \mathrm{Fe}(\mathrm{II})-+\mathrm{D}+\mathrm{H}_{2} \mathrm{O}$

are not accompanied by free radicals formation.

The comparison of transition metals catalytic activities, it has been noted that iron microcolloids posses higher catalytic activity than copper ions. The phenomenon of the catalytic activity of these metals can be explained by the oxidation-reduction potentials of the pairs $\mathrm{Fe}_{\mathrm{aq}}{ }^{3+} / \mathrm{Fe}_{\mathrm{aq}}{ }^{2+}(\varphi=0,771 \mathrm{~V}), \mathrm{Cu}_{\mathrm{aq}}{ }^{2+} / \mathrm{Cu}_{\mathrm{aq}}{ }^{+}(\varphi=0,153 \mathrm{~V}), \mathrm{O}_{2} / \mathrm{H}_{2} \mathrm{O}_{2}(\varphi=0,68$ $\mathrm{V}), \mathrm{H}_{2} \mathrm{O}_{2} / \mathrm{O}_{2}(\varphi=1,02 \mathrm{~V})$. The activation of oxygen or hydrogen peroxide can only take place when the metal redox potential has lower values than the redox potential of the pairs $\mathrm{O}_{2} / \mathrm{H}_{2} \mathrm{O}_{2}$ and $\mathrm{H}_{2} \mathrm{O}_{2} / \mathrm{O}_{2}[10]$.

The rate of substrate transformation can be influenced by various compounds present in natural waters. This influence can be observed through the variation of metals soluble forms and their reactivity capacities, by the formation of donor-acceptor complexes with the substrate and interaction with free radicals. As to the waters of our country, the most frequently encountered violations of the admissible limiting concentration are related to nitrogen compounds: $\mathrm{NO}_{3}^{-}, \mathrm{NO}_{2}^{-} \mathrm{NH}_{4}^{+}$.

The modification of the redox potential of the couple $\mathrm{Me}^{\mathrm{n}+} / \mathrm{Me}^{(\mathrm{n}-1)+}$ due to complexing has a significant impact on the reaction velocity for systems such as $\mathrm{Me}-\mathrm{Lig}-\mathrm{H}_{2} \mathrm{O}_{2}-\mathrm{S}$. It has been demonstrated that the more the ligand decreases the redox potential, the more effectively molecular oxygen and hydrogen peroxide are activated, and the more important is the catalytic activity of those compounds and the reaction velocity increases. In the case of increase of the redox potential of the couple, the role of the metal as an oxidant increases in the systems.

Addition of $\mathrm{NH}_{4}^{+}$ions in systems which contained copper ions as catalysts leads to the increase of the reaction velocity, proportionally to the metal concentration. The $\mathrm{NH}_{4}^{+}$and $\mathrm{Cl}^{-}$ions are ligands that increase the potential of the pair $\mathrm{Cu}^{2+} / \mathrm{Cu}^{+}$, thus stabilizing the reduced form of the metal.

Investigations regarding the catalytic activity of iron microcolloids showed that iron complexes with humic compounds don't posses catalytic activity. Although measurements regarding the influence of iron complexing with these ligands show that the potential of the pair $\mathrm{Fe}^{3+} / \mathrm{Fe}^{2+}$ decreases, which should have lead to a higher catalytic activity of these complexes, it is not confirmed in the case of evaluation of oxidation involving iron microcolloids in the presence of humic compounds. In this case, the reaction is inhibited, which can be explained by the formation of chelated complexes. Addition of these compounds into the copper-containing system doesn't imply any influences. The lack of any impact in the case of these ions can be explained by the fact that the redox potential of the pair $\mathrm{Cu}^{2+} / \mathrm{Cu}^{+}$is not at all changed or only slightly varied in the structure of these complexes.

The generalization of all stated above allows concluding the following.

In the natural aquatic environment, reducing agents are only oxidized catalytically by the dissolved oxygen and hydrogen peroxide. The process of catalytic oxidation involving hydrogen peroxide, which is the carrier of oxidative equivalents in surface waters, is more effective.

Depending on the donor's properties of being a ligand or not, the $\mathrm{H}_{2} \mathrm{O}_{2}$ reduction can be accompanied or not by the $\mathrm{OH}$ radicals formation. 
If redox ligands infiltrate into surface waters which contain $\mathrm{H}_{2} \mathrm{O}_{2}$ and copper ions, formation of $\mathrm{OH}$ radicals can be initiated, without the change of the metal's oxidation state, according to the reactions:

$\mathrm{Cu}^{2+}+\mathrm{DH}^{-} \longrightarrow \mathrm{CuDH}^{+}$

$\mathrm{CuDH}^{+}+\mathrm{H}_{2} \mathrm{O}_{2} \longrightarrow \mathrm{Cu}^{2+}+\mathrm{D}^{-*}+\mathrm{OH}$

Global equation: $\mathrm{DH}^{-}+\mathrm{H}_{2} \mathrm{O} \stackrel{\mathrm{Cu}^{+}+\mathrm{Cu}^{+}}{\longrightarrow} \mathrm{D}^{-}+\dot{\mathrm{O}} \mathrm{H}$

In the case of infiltration of reducers that don't exhibit ligand properties, two situations can appear, depending on the substrate concentration:

a) at high concentrations, $\mathrm{H}_{2} \mathrm{O}_{2}$ is consumed without free radicals formation:

$\mathrm{Cu}^{+} \mathrm{DH}_{2}+\mathrm{H}_{2} \mathrm{O}_{2} \rightarrow \mathrm{Cu}^{+}+\mathrm{D}+2 \mathrm{H}_{2} \mathrm{O}$

b) at small concentrations, substrates will not interfere significantly the process of $\mathrm{OH}$ radicals initiation, as a result of water oxidation by the $\mathrm{CuO}^{+}$particle:

$$
\mathrm{Cu}^{+}+\mathrm{H}_{2} \mathrm{O}_{2} \longrightarrow \mathrm{CuO}^{+}+\mathrm{H}_{2} \mathrm{O} \longrightarrow(\mathrm{CuOH})^{+}+\mathrm{OH}
$$

These cases show the main difference between the two redox states which can exist in natural waters: oxidative and quasi-reducing. In the first case, reducers initiate the decomposing of $\mathrm{H}_{2} \mathrm{O}_{2}$ with the formation of free radicals, in the second case, $\mathrm{H}_{2} \mathrm{O}_{2}$ is only consumed st the reducers oxidation.

Thiol-containing compounds exclude the copper ions from other redox processes, by transforming them into a biologically inaccessible form within the intermediate complex compounds. The presence of thiol substrates in natural waters can lead to the inhibition of chemical self-purification processes due to, on one hand, elimination of transition metals ions from the environment through their complexing, and, on the other, to the diminution or elimination of $\mathrm{H}_{2} \mathrm{O}_{2}$, which plays a very important part in the regulation of the natural waters redox state. All these contribute to the formation of the reducing state, toxic for living organism.

Comparing the catalysts activities, it can be confirmed that the oxidation process unfolds more intensely in the presence of copper, than iron.

The researches show that the velocity of substrates oxidation in natural waters is determined by the presence of copper ions, iron microcolloids, the content of $\mathrm{O}_{2}$ and $\mathrm{H}_{2} \mathrm{O}_{2}$. The influence of other water components is exhibited, as a rule, through the change of metals states in the solution.

\section{Photochemical transformations}

The majority of UV beams of the solar radiation are retained in the upper atmospheric layers (by the ozone layer) and only near-UV and VIS rays of the solar radiation spectrum $(\lambda \geq 300 \mathrm{~nm})$ reaches the Earth surface. In the range of wavelengths $300-350 \mathrm{~nm}$ the solar intensity significantly increases. Under the action of this radiation, various photochemical transformations take place in natural waters, greatly determining the self-purification capacity of surface waters $[3,39,40]$.

In the irradiated surface waters, two types of photodestruction can occur: direct photolysis and indirect (sensitization and induced) photolysis..

Organic compounds which absorb the actinic radiation $(\lambda=290-800 \mathrm{~nm})$, become instable and subsequently decompose. The direct transformation of a compound under the action of solar radiation can occur when the region of the solar spectrum radiation overlaps the absorption spectrum of the compound; this region is named "the spectrum of action". For the wide majority of compounds, the maximum of the spectrum of action is situated in the range 310-330 $\mathrm{nm}$. Most of the surface waters components absorb the near-UV radiation $(\lambda \leq 350 \mathrm{~nm})$, making this part of the solar radiation the most effective in the self-purification processes.

In the case of sensitization photolysis, the solar radiation is absorbed by the sensitizer and the excitation is then transmitted to another compound which undergoes changes. Humus substances have the greatest importance in these reactions. Humus substances (HS) can be divided in two groups: fulvic acids (FA), which are predominant and humus acids (HA). Fulvic acids serve as sensitizers, as their maximum of the spectrum of action is situated at $365 \mathrm{~nm}$. The absorption spectrum in the near-UV and far-UV regions (UVA and UVB) of humus acids is characterized by a maximum of high intensity at $\lambda=270 \mathrm{~nm}$, and for $\lambda>270 \mathrm{~nm}$ the absorbance decreases drastically, and is almost zero for $\lambda>300 \mathrm{~nm}$.

As a result of sensitization photolysis, intermediate non-radical active particles are formed: the electronically excited particles of the sensitizer $\left({ }^{3} \mathrm{~S}^{*}\right)$ and singlet oxygen $\left({ }^{1} \mathrm{O}_{2}\right)$, resulted during the passing of the excitation from the sensitizer to molecular oxygen:

$$
\begin{aligned}
& \mathrm{S} \stackrel{h v}{\longleftrightarrow}{ }^{1} \mathrm{~S}^{*} \longrightarrow{ }^{3} \mathrm{~S}^{*} \\
& { }^{3} \mathrm{~S}^{*}+\mathrm{O}_{2} \longrightarrow \mathrm{O}_{2}+\mathrm{S}
\end{aligned}
$$


Induced photolysis takes place in the presence of such active intermediates as the hydroxyl radicals $(\dot{O} H)$, carbonate (which results during the hydroxyl radicals interaction with the carbonate/bicarbonate ions), alkyl peroxide $\left(\mathrm{RO}_{2}\right)$, solvated electrons $\left(\overline{\mathrm{e}}_{\mathrm{aq}}\right)$, which are generated by the natural waters' constituents. The absorption of actinic radiation by the ODS and nitrates leads to the highest production of these species.

Several researchers point the fact that indirect photolysis is important for compounds which absorb in the far UV region, while direct photolysis - for compounds with absorption maxima at wavelengths $\geq 300 \mathrm{~nm}$ [30, 31].

Monica et al. studied the direct and indirect photochemical reactions in surface waters submitted to irradiation with the implication of several pharmaceutical compounds (atorvastatin (ATR), carbamazepine (CAR), levofloxacin (LEVO), sulfamethoxazole (SMX). They deduced that direct photolysis is important for the elimination of LEVO and SMX, while the presence of humus materials reduces the degradation velocity. In contrast, indirect photodestruction is the most important one for the limitation of ATR and CAR persistence, due to the fact that the destruction velocity increases in solutions which contain photo-producers of oxidants, humus acids. The explanation of the specific behaviour of these pharmaceutical products is given by their absorption spectra, for LEVO and SMX the absorption maxima are situated in the near UV region, while those for ATR and CAR - in the far UV [30].

Kępzyńsqi M. et al. have studied the photoxidation of phenol, sensitized by humic acids Aldrich (AHA), in aqueous solutions at neutral and alkaline $\mathrm{pH}$. Solutions containing phenol and various AHA concentrations were irradiated with monochromatic light at $\lambda=253,7 \mathrm{~nm}$ and polychromatic light in the wavelength range of 310-420 $\mathrm{nm}$. The results showed that addition of AHA to phenol solutions have different impact on its photoxidation. Thus, depending on the wavelength of the radiation and the AHA concentration, the process can be intensified or inhibited. For $\lambda=253,7 \mathrm{~nm}$ direct photolysis is the main pathway of phenol oxidation, while at $\lambda=310-420 \mathrm{~nm}$ the process is effectively sensitized by AHA [31].

In other works $[32,33]$ it has been deduced that the efficiency of direct photo-transformation depends not only on the presence of the benzoic ring and the chromophore group in the structure of aromatic compounds, which make possible the absorption of light in the UV-VIS range, but also on the type and position of the substituent in the benzoic ring. Prya $M$. et al studied the photocatalytic degradation at $\lambda=365 \mathrm{~nm}$ of 7 derivatives of phenol which contained 2 substituents from the range $\mathrm{Cl}, \mathrm{NO}_{2}, \mathrm{CH}_{3}$ in the presence of $\mathrm{TiO}_{2}$. The results indicated that chloromethylderivatives are destructed faster than chloronitrophenols [32]. Ksibi M.et al. have investigated the catalytic photodestruction in $\mathrm{TiO}_{2}$ suspension with UV radiation $(\lambda=280 \mathrm{~nm})$, at the $\mathrm{pH}$ of natural waters of 2 hydroxyphenols (hydroquinone and resorcine) and 3 nitrophenols (4-nitrophenol, 4-NF; 2,4-dinitrophenol, 2,4-DNF; 2,4,6-trinitrophenol, 2,4,6-TNF). According the initial velocity of destruction, nitrophenols placed in the range: $4 \mathrm{NF}>2,4 \mathrm{DNF}>2,4,6 \mathrm{TNF}$, and hydroxyphenols: resorcine $>$ hydroquinone [33]. In order to explain the results, we appealed to the Hammer $(\sigma)$ constant, which represents the relationship between structure and reactivity in the range of aromatic compounds. The results showed that the lowest the positive Hammer constant is, the highest the destruction constant. Thus, knowing this constant allows deducing the compound's susceptibility towards photocatalytic transformations.

Hydrogen peroxide, nitrates and nitrites are the most I portent photo inducers of processes of induced photolysis [40]. Under the action of the solar radiation on these compounds, the $\mathrm{OH}$ radicals are generated, and subsequently oxidize the pollutant.

Although nitrates are characterized by pronounced absorption at $\lambda<250 \mathrm{~nm}$, in the case of natural waters, which are irradiated by light of $\lambda \geq 300 \mathrm{~nm}$, their absorbance is quite low (for example for $\lambda=310 \mathrm{~nm}, \varepsilon_{310}=7,4 \mathrm{M}^{-1} \cdot \mathrm{cm}^{-1}$ ). Despite this, nitrates can't be neglected when it comes to discussing induced photolysis is natural waters. The role of nitrates in eliminating such contaminants as pesticides has been evaluated [41]. Frequently, this type of photolysis is applied in waste waters treatment procedures.

Usually, the thickness of the water layer where photochemical transformations take place is quite low and it doesn't exceed several meters; therefore, they are characteristic for surface layers of aquatic basins.

The variation of physical-chemical parameters of the aqueous environment influence the velocity of the selfpurification processes, as follows [29, 39]: the variation of the $\mathrm{pH}$ value leads to the decrease of the extent of hydrolysis in hydrolytic pollutants transformations; the increase of turbidity leads to the diminution of the extent of photochemical processes for the compounds with photochemical activity, but, $t$ the same time, sensitized photolytic processes are intensified, leading to the increase of the velocity of photochemical processes of free radicals initiation; contamination with compounds which posses ligand properties leads to the distribution of metal forms, which, at its turn, will influence the mass transfer processes and will change the catalytic activity of metals; temperature increase will intensify the temperature-depending processes, such as catalytic hydrolysis and oxidation; radioactive pollution will increase the velocity of $\mathrm{OH}$ radicals initiation and their stationary concentrations, which could have an impact on the biogenic elements cycles; pollution with S-containing compounds will reduce the $\mathrm{Cu}^{2+}$ ions, forming stable complexes which 
are biologically inaccessible to living organisms. As a result, free radical oxidation is inhibited, accompanied by the appearance of toxicity effects for the organisms which are involved in an intense exchange of water with the environment.

There is a continuous unfolding of biotic and abiotic processes of formation of interacting reducing and oxidizing equivalents in natural waters. The result of this interaction is determined by the ratio between the oxidation equivalents fluxes - hydrogen peroxide $\left(\omega_{\mathrm{i}}\right)$ and reducing equivalents - reducing compounds $\left(\mathrm{DH}_{2}\right)$ which interact with it $\left(\omega_{\mathrm{r}}\right)$ effectively. Reducers which infiltrate into the aquatic environment are oxidized by hydrogen peroxide, accompanied or not by the conjugated radical oxidation processes. If oxidation equivalents fluxes predominate $\left(\omega_{\mathrm{i}}>\omega_{\mathrm{r}}\right)$, the environment is in an oxidative state. By contrast, in case that reducing fluxes are superior to the $\mathrm{H}_{2} \mathrm{O}_{2}$ flux $\left(\omega_{\mathrm{r}}>\omega_{\mathrm{i}}\right)$ the quasi-reducing state appears (reducers will be slowly oxidized by the dissolved oxygen).

The monitoring of free radical processes in natural waters is necessary for estimating the self-purification capacity of waters, as well as for preventing the phenomenon of toxicity towards mature living organisms in waters. Regarding the efficiency of radical self purification, the increase of the stationary $\dot{O} H$ radicals concentration is a positive factor. However, along with the increase of radicals concentrations, increases the danger of involving into the radical processes not only polluting compounds, but also the components of the environment which determine the structure and stability of hydro-biocenoses, or the perturbation of the manganese ions biogeochemical cycle can occur.

The increase of the stationary $\dot{O} H$ radicals concentrations is the result of the increase of the initiating processes velocities, or the decrease of the constant which describes the radical's interaction with various "traps". The velocity of initiation increases with the pollution of the environment, especially with nitrates and nitrites (particularly at abundant rains) or due to the radioactive pollution.

\section{References}

[1] Каплин, В.Т.; Панченко, С.Е.; Шлычкова, В.В., Ж. Гидрохим. матер. Гидрометеоиздат: Обнинск 1968, Т. XLIV; c. 183.

[2] Головлёва, Л.А.; Филькинштейн, 3.И.; Перцова Р.Н. Тез. докл. сов.-амер. симп.: Прогнозирование поведения пестицидов в окружающей среде, Ереван, 1981, с. 6-7.

[3] Скурлатов, Ю.И.; Дука, Г.Г.; Эрнестова, Л.С. Ж. Изв. АН МолдССР, сер. биол.-хим. наук, Штиинца: Кишинёв, 1983, 5; с.3-20.

[4] Семеняк, Л.В.; Штамм, Е.В.; Скурлатов, Ю.И.; Швыдский, В.О. и др. Мат. ІІІ Межд. Симпоз: Критерии самоочищ. способ. и качества природ. водной среды. Комплекс. глобал. мониторинг состояния окруж. природ. водной среды, Гидрометеоиздат: Ленинград, 1986, с. 209-216.

[5] Эрнестова, Л.С.; Скурлатов, Ю.И. Ж. Физ. Хим. Наука: Москва, 1995, 69, 7; с. 1159-1166.

[6] РД 52.18.24.83-89. Методические указания. Методика определения кинетических показателей качества поверхностных (пресных) вод; Гидрометеоиздат: Москва, 1990; 36 с.

[7] Скурлатов, Ю.И.; Эрнестова, Л.С.; Штамм, Е.В.; Шпотова, Т.В.; Калинин Б.Б. Ж. Докл. Акад. Наук СССР. Наука: Москва, 1984, 276, 4; с. 1014-1016.

[8] Штамм, Е.В. В сб.: Эколог. Химия водной среды. Мат. I Всес школы, Кишинёв, 1988, с. $278-294$.

[9] Штамм, Е.В.; Пурмаль, А.П.; Скурлатов, Ю.И. Журн. Успехи химии. Наука: Москва, 1991, 60, 11; с. 2373-24062.

[10] Сычёв, А.Я.; Травин, С.О.; Дука, Г.Г.; Скурлатов, Ю.И. Калитические реакции и охрана окружающей среды; Штиинца: Кишинёв, 1983; с.88.

[11] Buxton, B.V.; Greenstock, C.L.; Helman, W.P.; Ross, A.B. J.Phys. Chem. 1988, 17, 513-886.

[12] Mopper, K.; Zhou, X., J. Science. 1990, 250, 661.

[13] Vaughan, P.; Blough, N., J. Environ. Sci. Technol. 1998, 32, 2947.

[14] Bunduchi, E.; Duca, Gh.; Gladchi, V.; Goreaceva, N.; Mardari, I. Chemistry Journal of Moldova. General, Industrial and Ecological Chemistry. Ed. ASM: Chisinau, 2006, 1, 1; pp. 68.

[15] Grannas, A. M.; Martin, Ch. B.; Chin, Yu-Ping, Platz, M., Biogeochemistry. 2006, 78. p.51

[16] Zepp, R.G.; Cline, D.M., J. Envir.Sci.Technol. 1977,11, 359.

[17] Hoigné, J.; Bader, H., J. Ozone: Science and Engineering. 1979, 1, 357.

[18] Mill, T.; Hendry, D.E.; Richardson, H., J. Sci. 1980, 207, 286.

[19] Zafiriou, O.C., J. Chem. Oceanography.1983, 8, p.339.

[20] Штамм, Е.В. Автореф.: Кислородозависимые окислительно-восстановительные и фотохимические процессы в природных водах, Москва, 1992. 
[21] Дука, Г.Г. Автореф.: Механизмы экохимических процессов в водной среде, Одесса, 1988.

[22] Романчук, Л.С. Автореф.: Окислительно-восстановительный катализ и фотолиз некоторых оксо- и оксикислот, Кишинёв, 1990.

[23] Эрнестова, Л.С. Автореф.: Методология и методика изучения состояния водных экосистем на основе кинетического подхода, Обнинск, 1995

[24] Пурмаль, А.П.; Скурлатов, Ю.И., Ж. Природа. Наука: Москва, 1984, 10, с. 94-102.

[25] Emerson, S.; Kalhorn, S.; Iacobs, L. et al. J. Geochim.Cosmochim Acta.1982, 46, 1073-1079.

[26] Эрнестова, Л.С.; Скурлатов, Ю.И.; Фурсина, А. Ж. Физ. Хим.1984, 58; с.914-918.

[27] Duca, Gh.; Gladchi, V.; Romanciuc, L. Procese de poluare şi autoepurare a apelor naturale; CE USM: Chişinău, 2002, p.3-140.

[28] Gladchi, V.; Bunduchi, E. In Abstracts: Ecological chemistry, october 11-12, 2002, Chisinau, p. 42.

[29] Скурлатов, Ю.И.; Дука Г.Г., Mediul ambinat. Ministry of Ecology: Chisinau, 2003,3; pp. 4-11.

[30] Monica, W. Lam and Scott A. Mabury. Aquatic Sciences. Vol. 67, Nr.2, 2005, p. 177-188.

[31] Kępczyńsqi, M.; Czosnyka, A.; Nowakowska, M., J. Photochemistry and Photobiology. 2004, 79(3), $259-264$.

[32] Prya, M.; Giridnar, M. J. of Photoch. and Photob. A: Chemistry. 2006, 179, 256-262.

[33] Ksibi, M.; Zemzemi, A..; Bouqchina, R. J. of Photoch. and Photob. A: Chemistry. 2003, 159, 61-70.

[34] Штамм, Е.В.; Скурлатов, Ю.И.; Пурмаль, Ю.П. Ж. Физ. Хим.1987, 51, 12; сс. 3136-3139.

[35] Лапин, И.А..; Красюков, В.Н. Водные ресурсы. №1, 1988, сс. 134-145.

[36] Линник, П.М.; Набиванец, Б.И.; Брагинский Л.П. IV Межд. симпоз. по гомог. катал.: Формы существования, основные закономерности превращений и биологическая роль соединений тяжёлых металлов в природных водах. 1994; с. 237-238.

[37] Секи Хумитаке. Органические вещества в водных экосистемах; Гидрометеоиздат: Ленинград, 1986 ; с. $55-58$.

[38] Xiani Liu, Dong Xu, Feng Wu, Zhenhaun Lia, Jiantong Liu, Nansheng Deng., J. Photoch. and Photob., 2004, 79(3), 259-264.

[39] Duca, Gh.; Scurlatov, Yu. Ecological chemistry; Publishing Center MSU: Chisinau, 2002; pp. 154-196.

[40] Сычёв, А.Я.; Дука Г.Г. Фундаментальные и прикладные аспекты гомогенного катализа металлокомплексами; Изд. центр Молд. Гос. Унив.: Кишинёв, 2002, Ч.І и II.

[41] Sharpless Charles, Seibold Deborah, Linden K., J. Aquat. Sci. 2003, 65, 359-366.

[42] Borodaev, R., Anal. Ştiinț. ale USM, seria „Ştiințe chimico-biologice”. CE USM: Chişinău, 2002; p.401-407.

[43] Duca, Gh.; Goreaceva, N.; Romanciuc, L.; Gladchi, V., J. Intellectus., Ştiința: Chişinău, 1999, 4; p.62-68.

[44] Семеняк,Л.В.Автореф.:Эколого-химическиезакономерностиформированиябиологическойполноценности водной среды, Москва, 1996. 